\title{
Walking on the Molecular Pathway: m-TOR Inhibition in the Liver Transplant Setting
}

\author{
Francesca Romana Ponziani*, Maria Luisa Novi, Emanuele Rinninella and Antonio Gasbarrini
}

Department of Internal Medicine, Catholic University of Rome, Largo A. Gemelli 8, 00168, Rome, Italy

\begin{abstract}
Hepatocellular carcinoma (HCC) is a major problem worldwide, representing the fifth most common tumor among the general population [1]. Several molecular pathways seem to be involved in HCC growth and progression, realizing an intricate mechanism of proliferative and angiogenetic stimulation and inhibiting apoptosis. The recent identification of these molecular pathways has improved our knowledge of HCC tumorigenesis and has setted up a more specific approach to HCC treatment. However, since non advanced HCC is one of the most common indications for liver transplantation, the recent novelties in pharmacologic inhibition of HCC growth mechanisms have opened new interesting opportunities in recipients' immunosuppressive treatment. M-TOR inhibitors belong to the group of rapamycine analogues, are used as second line immunosuppressive drugs and capable to inhibit one of the most active molecular pathways in HCC cells: the m-TOR pathway. In this review, we explain the mechanism and the molecular elements involved, up- and downstream, in m-TOR activation, providing an overview of the other features of HCC tumorigenesis too. Moreover, we describe the effects of m-TOR inhibition on HCC cells in vitro and in animal models, as well as on liver transplant recipients at risk of or with a manifest tumor recurrence and on de novo post-transplant malignancies. Finally, we discuss the possible efficacy of a proper combined therapy, well tolerated by patients and active against multiple molecular targets, to obtain a synergistic effect on the tumor mass with the greatest benefit for patients' survival and quality of life.
\end{abstract}

Keywords: m-TOR, m-TOR inhibitors, hepatocellular carcinoma, liver transplantation, immunosuppression.

\section{INTRODUCTION}

Hepatocellular carcinoma (HCC) is the fifth most common tumor among the general population and the most common among cirrhotic patients [1]. Although, in the last few years, the international guidelines have strongly recommended a strict follow-up of cirrhotic patients to recognize tumoral lesions at early stage, a curative therapy is applicable only in $1 / 3$ of cases [2]. Among the available curative treatments, liver transplantation has a better outcome than surgical resection or local ablation $[3,4]$. The first liver transplant experiences in HCC patients produced scarce results in terms of outcome and disease recurrence; nowadays, since the introduction of the Milan criteria [5], the overall survival rate is of about $60-70 \%$ or better at five years after transplantation [6,7]. However, in case of tumors exceeding the Milan criteria, data are contrasting [5]. Unfortunately, despite patients' selection to avoid tumor recurrence, it may be possible and is more frequent within the first two years after liver transplantation, with the feature of a local or a metastatic lesion in lung or bone [8]. At the time of recurrence, patients' survival is significantly reduced [9]. Post-transplantation chemotherapy has reported variable results [10-13], but there is no treatment capable to avoid HCC recurrence yet. Moreover, liver transplant recipients have a three to five fold increased risk to develop a new extrahepatic tumor [14-18]. Virtually, each organ could be

*Address correspondence to this author at the Department of Internal Medicine, Catholic University of Rome, Largo A. Gemelli 8, 00168, Rome, Italy; Tel: +39-347-1227242; Fax: +39-06-30156018;

E-mail: francesca.ponziani@yahoo.it involved, even if non-melanotic skin cancers, post-transplant lymphoproliferative disease (PTLD), and Kaposi's sarcoma are the most frequently reported tumors [14-16, 19-21]; about $20 \%$ of post-transplantation overall mortality is imputable to de novo tumors [22]. The principal explanatory reason could be identified with the immunosuppressive treatment, necessary to avoid graft rejection. Patients' immune system loses its competence in recognizing and fighting tumoral cells and, at the same time, the guard against oncogenic viruses is reduced. Furthermore, immunosuppressive drugs might be responsible for promoting tumor development in solid organ transplant recipients through a non-immunologically-mediated mechanism too [23]. In experimental tumor models, cyclosporine favors the growth of invasive and metastatic tumor cells [24]; a similar effect has been reported for tacrolimus too [25]. This process seems to be related to TGF-b and VEGF overexpression [26]. Clinical studies, such as those from Vivarelli et al. [27, 28], reported an increased risk of $\mathrm{HCC}$ recurrence in patients overexposed to tacrolimus and cyclosporine, even if these studies were mainly retrospective [29].

\section{THE RECENT DISCOVERY OF M-TOR INHIBITORS}

Rapamycin (sirolimus; Rapamune, Wyeth) is a macrolide antibiotic with well-known properties in the regulation of immune system, cellular proliferation and angiogenesis, isolated in the 1970s from a bacterium of the soil (Streptomyces hydroscopicus) in the island of Rapa Nui [30, 31]. Rapamycine multiple effects are due to the inhibition of a conserved checkpoint protein-kinase, called mTOR (mammalian target of rapamycine), involved in a complex 
Table 1. Principal Characteristics of mTOR Inhibitors [30]

\begin{tabular}{|c|c|c|c|c|c|c|}
\hline $\begin{array}{c}\text { mTOR } \\
\text { inhibitor }\end{array}$ & Absorption & Half-life & Metabolization & $\begin{array}{c}\text { Dose } \\
\text { adjustment } \\
\text { required by age }\end{array}$ & $\begin{array}{l}\text { Dose adjustment } \\
\text { required by liver } \\
\text { function }\end{array}$ & $\begin{array}{l}\text { Dose adjustment } \\
\text { required by renal } \\
\text { function }\end{array}$ \\
\hline Sirolimus & $\begin{array}{l}14 \% \text { for liquid } \\
\text { solution; increased by } \\
\text { tablets or lipid meal }\end{array}$ & $62 \pm 16 \mathrm{~h}$ & $\begin{array}{l}\text { CYP3A4 and P- } \\
\text { glycoprotein }\end{array}$ & None & $\begin{array}{l}\text { Child A/B increased } \\
\text { biodisponibility }\end{array}$ & None \\
\hline Temsirolimus & Intravenous & $\begin{array}{l}17.7 \mathrm{~h}(73.3 \mathrm{~h} \text { for } \\
\text { its metabolite } \\
\text { sirolimus })\end{array}$ & $\begin{array}{l}\text { CYP3A4 and P- } \\
\text { glycoprotein }\end{array}$ & None & No data & None \\
\hline Everolimus & $\begin{array}{l}90 \% \text {; decreased by } \\
\text { lipid meal }\end{array}$ & $26-38 \mathrm{~h}$ & $\begin{array}{l}\text { CYP3A4 and P- } \\
\text { glycoprotein }\end{array}$ & None & $\begin{array}{l}\text { 2-fold increased } \\
\text { biodisponibility }\end{array}$ & None \\
\hline
\end{tabular}

pathway of interactions: the m-TOR pathway. Apart from sirolimus, several molecules can inhibit m-TOR activity; at present, everolimus and temsirolimus are the most studied. Generally, m-TOR inhibitors are similar to tacrolimus, but without any anti-calcineurin effect [32].

The nucleus of m-TOR inhibition is easy to summarize: after binding its intracellular receptor, the FK-binding protein (FKBP12), rapamycin-FKBP complex binds the Cterminal kinase domain of m-TOR inhibiting its action [33]. This is the simple, but, at the same time, complex mechanism of action of rapamycin analogues.

\section{THE M-TOR PATHWAY}

What is m-TOR pathway and how does it works? MTOR is a conserved checkpoint serine-threonine kinase belonging to the phosphatidylinositol 3-kinase (PI3K)kinase-related kinase superfamily, involved in both cell growth and cell cycle progression [34, 35]. M-TOR functions result from the integration of multiple signals, derived from growth factors and reflecting cellular energy storage and hypoxia (Fig. 1). In specimen, growth factors may influence m-TOR through the PI3K-Akt pathway, while the intracellular energetic level through LKB1-TSC pathway

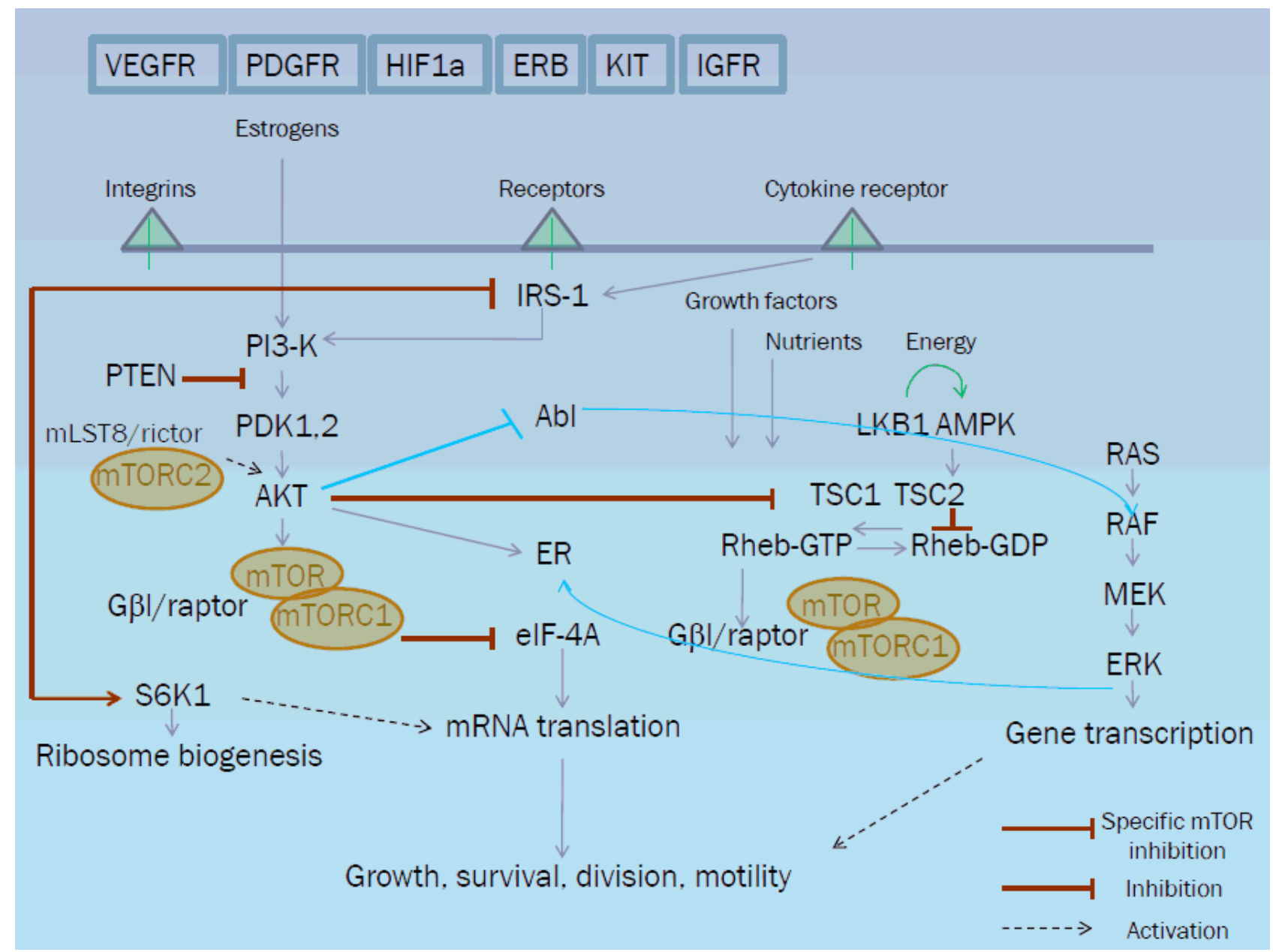

Fig. (1). m-TOR signaling and related pathways [30]. 
[36]. In response to extracellular growth stimulation, including insulin and insulin-like growth factor 1 (IGF-1), PI3K recruited by the insulin receptor substrate (IRS) generates phosphatidylinositol-3, 4, 5- triphosphate (PIP3), which activates phosphatidylinositol-dependent kinase-1 (PDK1) and Akt [37]. Activated Akt inhibits the tuberous sclerosis complex (TSC) [38, 39], a GTPase-activating protein; the main effect is the activation of GTP-bound protein Rheb, which in turns removes the negative control on mTOR [30, 40, 41]. In case of energy deficiency (reduction of ATP or amino acids intracellular levels), LKB1 activates 5'AMP-activated protein kinase (AMPK), which activates TSC complex; the result is inhibition of Rheb and, consequently, of m-TOR [30, 41-43]. Therefore, energy deficiency leads to m-TOR inhibition stopping the cell cycle in the G1 phase, since the m-TOR pathway initiates the translation of proteins necessary for cell cycle progression; in contrast, the response to growth stimulation is m-TOR activation [44]. Activated m-TOR may form many complexes with other proteins [45-49]. The complex m-TORRaptor (m-TORC1) leads to the phosphorylation of eukaryotic initiation factor 4E binding protein-1 (4E-BP1) and protein S6 kinase 1 (S6K1), both regulators of protein translation [37]; m-TORC1 is rapamycine sensitive and used in laboratory to quantify m-TOR activity. The complex mTOR-Rictor (m-TORC2), instead, is not influenced by rapamycine and determines the full activation of Akt. In conclusion, the S6K1 pathway leads to the translation of mRNAs encoding ribosomal proteins, elongation factors and insulin growth factor-II, while the 4E-BP1 to the translation of mRNAs encoding cell cycle regulators, such as cyclin D1 or ornithine decarboxylase, or growth factors [44, 50]. Rapamycin has also some effects on tumor angiogenesis [23], related to the reduction of VEGF production and of endothelial response to VEGF [51]. The hypoxia inducible factor (HIF-1) plays a pivotal role in regulating this response. Indeed, when the oxygen tension is low, angiogenesis is promoted by HIF-1 through VEGF production. Since HIF1 is molecularly located downstream of m-TOR, it is consequently inhibited by rapamycin [52-54]. Moreover, m-TOR pathway is the scenario of multiple interactions and feedbacks. Indeed, m-TORC1 may inhibit m-TOR activation by insulin through S6K1. M-TORC1 may compete with mTORC2 too, through the activation of Akt. M-TORC2 activates Akt, which inhibits TSC2 complex, stimulating the formation of $\mathrm{m}$-TORC1; on the other hand, m-TORC1 may antagonize mTORC2 and reduce Akt activity [55]. Hyperactive mTORC1 may also inhibit insulin receptor substrate (IRS) upstream in the m-TOR pathway. Interestingly the anti-oncogen PTEN (phosphatase and tensin homologue deleted on chromosome 10), modulating PIP3 formation, may reduce Akt activity [41].

\section{THE M-TOR PATHWAY, TUMOR DEVELOPMENT AND HEPATOCELLULAR CARCINOMA}

How could m-TOR pathway be responsible for tumor development? As discussed above, m-TOR pathway involves several components, complexly linked each to the other. Mutations of PTEN, Akt, TSC1 and 2, PI3K-dependent signaling and aberrant protein translation can lead to $\mathrm{m}$-TOR hyperactivation and promote oncogenesis. It has recently been shown that inflammation is linked to the m-TOR pathway via tumor necrosis factor signaling [56, 57]. Moreover, alterations of m-TOR pathway have been demonstrated in several tumor- predisposing syndromes, such as tuberous sclerosis (TSC1/2), Peutz-Jeghers syndrome (LKB1), and Cowden's syndrome (PTEN) [58]. As regards HCC, some studies have assessed the expression of $\mathrm{m}$-TOR related markers in tumor cells and liver tissue. Sahin et al. [59] reported that cells strongly positive for $\mathrm{m}$-TOR or $\mathrm{p}$ (phosphorilated) m-TOR did not show any difference in Ki67 proliferation index, while the normal liver tissue was always weakly positive. Hepatocellular carcinoma cells were also highly positive for S6K1 expression. Sieghart et al. [60] concluded that $40 \%$ of transplanted patients with HCC present an hyperactivation of $\mathrm{m}$-TOR pathway; however, no correlation was found with the expression any single protein (i.e. Akt, S6K1, 4EBP1, PTEN). Baba et al. [61] highlighted the increased expression of $\mathrm{p}-\mathrm{S} 6 \mathrm{~K} 1$ in the cytoplasm of HCC cells, while in the normal liver tissue it was absolutely less represented. Moreover, p-S6K1 hyperexpression was inversely related to cellular differentiation, and directly related to the expression of cyclin D1 in HCC cells. Apparently, there was no relation between $\mathrm{p}-\mathrm{S} 6 \mathrm{~K} 1$ expression and the etiology of liver disease. Finally, Villanueva et al. [62] reported the hyperexpression of m-TOR-Rictor (m-TORC2) complex in those cells with an increased number of DNA copy. Furthermore, increased levels of m-TOR activation products were found in $48 \%$ of HCC while in only $19 \%$ of the normal liver tissue, and were associated to less differentiated tumors, advanced BCLC stage, higher levels of alpha-fetoprotein and larger tumor volume. In addition, protein localization in hepatocellular carcinoma cells was almost cytoplasmatic. The presence or the absence of these alterations may, obviously, condition cancer cell sensitivity to m-TOR inhibitors.

Another interesting aspect is that m-TOR pathway is expressed in a wide number of cells of the human body, and its stimulation may lead to protean manifestations of different biological significance [63-65]. The most investigated one is T-cells response to proliferative and survival stimuli through m-TOR activation [66-68]; m-TOR inhibition can block effector T-cell expansion, producing immunosuppression [69]. In contrast, regulatory $\mathrm{T}$ cells may respond to mitogen-dependent activation through m-TOR but, also, through other pathways of signaling; thus, they are less influenced by rapamycine and its analogues and could be selected for expansion if stimulated.15 It is only one of the multiple features of m-TOR pathway, which highlights a complex network of interactions with local microenvironment and systemic perturbations, influencing the activity of a great number of cells in different tissues.

\section{M-TOR INHIBITION AND TUMOR PREVENTION: THE GREAT IMPACT ON LIVER TRANSPLANTA- TION FOR HEPATOCELLULAR CARCINOMA}

Based on the mechanisms discussed in this article, mTOR pathway inhibition has a great impact in the prevention of tumor development. The mTORC1complex is the only FKBP12-rapamycin sensitive target. Since this interaction is irreversible, m-TOR availability and, consequently, the formation of m-TORC2 are sensibly reduced [70]. 
Several studies confirmed that rapamycine reduces tumoral cells' proliferation in vitro $[48,71,72]$ and the expression of molecules associated to tumor progression and metastatic potential in mice [73]. Koehl et al. [74] reported that sirolimus prevents rejection, inhibits tumor growth and prolongs survival in models of cardiac allograft with tumor grafts, while, in the same conditions, cyclosporine is only able to prevent rejection. The efficacy of sirolimus as anticancer agent depends on the dose, so that low nanogram per milliliter concentrations might produce a potent antiangiogenic and a potential antiproliferative effect, whereas higher doses might have a direct cytotoxic effect on tumor cells [75].

Several clinical trials and case reports confirmed data from in vitro and animal experimentation. A prospective, randomized trial reported the efficacy of temsirolimus in the treatment of advanced renal adenocarcinoma [76]; other studies underlined the same anti-tumor activity in the transplant setting [77-79]. In liver transplant recipients too, de novo or recurrent malignancies are an important cause of morbidity and mortality $[80,81]$, and m-TOR inhibitors might open new perspectives in the management of recipients with tumors or with a high risk of tumor development. In specimen, the experience of Kneteman et al. [82] has been precious to understand rapamycine analogues utility in the liver transplant setting. In this study, HCC patients undergoing liver transplantation received sirolimus-based immunosuppression reducing CNIs and steroids administration; 19 patients were transplanted within the Milan criteria, 21 beyond. As a result, tumor-free 4-year survival was of $81.1 \%$, with less than $5.3 \%$ recurrence (1 patient), for recipients transplanted within the Milan criteria, while it was of $76.8 \%$ with about $19 \%$ of recurrence ( 4 patients) for patients responding to the extended criteria. The rate of rejection was of $30 \%$, but no case of graft loss occurred. Yao et al. [5] reported an overall $11 \%$ rate of recurrence ( 8 patients) in 70 liver transplant recipients meeting or not the Milan criteria, on treatment with cyclosporine or tacrolimus; 3 of them, about $4 \%$ of the entire population, met the Milan criteria. As noted in an interesting editorial by Wall [83], in patients meeting the Milan criteria, Kneteman results where almost the same of those obtained by Yao in the same group of patients receiving CNI-based immunosuppression; on the other hand, there was a consistent gain in tumor-free survival in patients beyond the Milan criteria. Subsequently, Kneteman's group [84] reported data from the follow-up of 70 OLT recipients treated with a sirolimus-based protocol; tumor recurrence was observed in about $6 \%$ of patients meeting the Milan criteria, while it was more frequent (about $17 \%$ ) in those beyond the Milan criteria. In the former group, 1 and 4-year tumor-free survival was of $83 \%$ and $73 \%$ respectively, in the latter of $83 \%$ and $75 \%$. Graft rejection occurred in half of patients.

m-TOR inhibitors seem to be able to delay tumor recurrence and prolong patients' survival after recurrence, with some effects on metastases spreading too. In a large series of kidney transplant recipients [85] presenting de novo post-transplant tumors, the medium survival of patients not eligible for surgery and converted to sirolimus was of 14.5 months, versus 3 months of those receiving a standard immunosuppressive regimen. Moreover, 12- and 20 monthssurvival in the non-sirolimus group was significantly lower
(6.7\% and $0 \%$, respectively). After the conversion to a sirolimus-based immunosuppressive regimen, regression of pulmonary metastases or a long recurrence-free interval after surgery of ovarian metastases have also been observed [86, 87]. By the way, in the previously mentioned study by Sieghart et al. [60], m-TOR hyperexpression seems to have no influence on disease-free interval or overall survival; furthermore, Zimmerman et al. [88] excluded an effective survival benefit on about $37 \%$ of patients receiving sirolimus.

Finally, another mechanism advocated to explain the effects of rapamycin analogues on HCC cells is proapoptotic stimulation, through the activation of caspase-3, disruption of mitochondrial membrane potential, downregulation of the anti-apoptotic protein Bcl-2 and upregulation of the pro-apoptotic protein Bcl-xl [89].

\section{M-TOR INHIBITION PREVENTS DE NOVO TUMORS DEVELOPMENT IN TRANSPLANT RECIPIENTS}

Since the m-TOR pathway is abnormally active and altered in some tumoral cells, m-TOR inhibition may not only prevent the recurrence of pre-existing tumors in transplant recipients, but also the development of de novo tumors. In animal models, rapamycine prevents tumor development in p53-mutated mice [90] and the clinical data available so far suggest a pivotal role of $\mathrm{m}$-TOR inhibition in preventing de novo tumors development after transplantation. A wide number of retrospective studies reported, in renal transplant recipients receiving $\mathrm{m}$-TOR inhibitors, a significantly lower incidence of de novo post-transplant tumors, in respect to those receiving CNIs [91-97].

In this regard, the treatment of Kaposi sarcoma, whose incidence is 500 times higher among transplant recipients, is the most convincing experience. In renal transplant recipients who developed Kaposi sarcoma receiving CNI-based immunosuppression, the introduction of sirolimus with or without CNI withdrawal produced sarcoma complete regression [23]. Regression or stabilization of Kaposi metastatic and cutaneous lesions has also been reported [98-101]. However, sirolimus benefits are not so evident in patients with extensive cutaneous or visceral Kaposi disease and cases of failure have also been reported [81, 101-104]. Whether the regression of Kaposi lesions could be due to sirolimus introduction rather than to CNI withdrawal [105, 106], is still to be demonstrated.

Apart from Kaposi sarcoma, rapamycin immunosuppressive treatment may also reduce the incidence of skin tumors in transplant recipients [99, 107-112]. Moreover, several data show the complete regression or remission of PTLD after introducing m-TOR inhibitors-based immunosuppression [113-121]. Two studies [122, 123] reported that patients with various post-transplant malignancies (lung, prostate, colon, stomach, esophagus, breast, larynx etc.) might benefit of sirolimus administration. In both these studies, a conspicuous number of patients had a complete remission (about $65 \%$ and 50\%, respectively), with an increased survival in respect to the control group. However, other reports are contrasting [124-126], and all these evidences need to be confirmed. 


\section{THE NEW ERA OF MOLECULAR TARGETING IN HCC MANAGEMENT: A COMBINED APPROACH}

In addition to the previously discussed m-TOR pathway, it is now clear that HCC proliferation is strongly dependent by the mitogen-activated protein kinase pathway too. Four kinases are involved: Ras, Raf, the mitogen-activated protein extracellular kinase (MEK), and extracellular signal-regulated kinase (ERK) [127]. This pathway is crucial for cell proliferation and could be activated in $\mathrm{HBV}$ and $\mathrm{HCV}$ infection or in presence of growth factors as well as in hepatocellular tumors, in specimen those with an aggressive phenotype [128]. However, mutations of Ras pathway are relatively rare in HCC cells $[129,130]$; furthermore, Rasbinding proteins, such as RASSF1A and NORE1A, may counterbalance Ras pathway activation by inhibiting Rasdependent mitogenic stimulation and promoting apoptosis $[131,132]$.

Among human tumors, HCC is one of the most hypervascularized, overexpressing VEGF in proportion to microvascular density and in relation to the invasive and metastatic potential and PDGF-B, which is directly involved in tumor angiogenesis [133].

Taking in account the different and complex modalities of signaling responsible for tumor growth, invasion and spreading, and referring in particular to $\mathrm{HCC}$, different pharmacological agents should be combined to obtain a synergistic therapeutic effect and the highest efficacy.
Sorafenib is an oral multikinase inhibitor used as standard of care in advanced cases of HCC, capable to block Raf/MEK/ ERK pathway VEGFR-2, VEGFR-3, PDGFR-b, Ret and cKit [134]. The inhibition of other pathways of intracellular signaling may contribute to sorafenib efficacy [135].

A study by Wang et al. [136], successively confirmed by Newell et al. [133] and Huynh et al. [128, 135], reported that rapamycin (or its analogues), alone and in combination with sorafenib, inhibits primary and metastatic tumor growth in human HCC xenografts; moreover, combined therapy seems to be more effective in reducing tumor size and angiogenesis than a single agent therapy. The combination of antiproliferative, proapoptotic and antiangiogenetic effects may explain these results. This attractive, orally administered and welltolerated new modality of combined treatment should be seriously considered to design clinical trials, to assess its efficacy on disease progression and, consequently, the benefits on patients' quality of life.

Finally, it could be interesting to evaluate whether the administration of rapamycine analogues may lead to a specific resistance. As previously discussed in this article, the inhibition of m-TOR pathway may produce the overexpression of such molecules, as Akt, upstream of m-TOR, leading to a potential mean of resistance. Therefore, a combined therapeutic approach might prevent the occurrence of drug resistance, with a more complete regulation of the complex network of m-TOR pathway interactions [137].

Table 2. Adverse Effects of mTOR Inhibitors [138]

\begin{tabular}{|c|c|c|}
\hline Adverse Effect & Clinical Onset and Characteristics & Incidence \\
\hline Mucositis & $\begin{array}{l}\text { Clinical onset: rapid onset (within } 5 \text { days), usually not severe } \\
\text { (grade 1-2) reversible after withholding treatment. } \\
\text { Characteristics: } 1-3 \text { oval ulcers surrounded by erythema on the } \\
\text { mucosa of the lips, lateral tongue, buccal mucosa and soft palate }\end{array}$ & $\begin{array}{l}75 \% \text { temsirolimus } \\
78 \% \text { deforolimus } 41 \% \text { everolimus }\end{array}$ \\
\hline $\begin{array}{l}\text { Pulmonary } \\
\text { Toxicity }\end{array}$ & $\begin{array}{l}\text { Clinical onset: after } 6 \text { months to } 1 \text { year from the onset of } \\
\text { therapy. } \\
\text { Characteristics: dyspnea and dry cough, fatigue and fever, } \\
\text { ground glass opacities or lung parenchymal consolidation at } \\
\text { chest x-ray, restrictive pulmonary disease pattern. Frequent in } \\
\text { patients with previous pulmonary disease }\end{array}$ & $5-50 \%$ incidence \\
\hline Skin toxicity & $\begin{array}{l}\text { Clinical onset: during the first few weeks of treatment, usually } \\
\text { not severe (grade 1-2), spontaneous resolution or after topic } \\
\text { treatment. } \\
\text { Characteristics: maculopapular or acneform rash on the face and } \\
\text { neck, dryness, eczema, skin discoloration, nail dystrophy }\end{array}$ & $>50 \%$ incidence \\
\hline $\begin{array}{l}\text { Bone Marrow } \\
\text { toxicity }\end{array}$ & $\begin{array}{l}\text { Bone marrow suppression, predominant for megakaryocytes, } \\
\text { reversible, dose and concentration dependent }\end{array}$ & $\begin{array}{l}\text { Thrombocytopenia was reported about } 29-33 \% \text { with } \\
\text { temsirolimus, } 10 \% \text { for everolimus, and } 20-25 \% \text { for deforolimus. } \\
\text { Leucopenia has also been reported up to } 27 \% \text { for temsirolimus, } \\
38 \% \text { for deforolimus, neutropenia is less common }\end{array}$ \\
\hline Renal toxicity & $\begin{array}{c}\text { Discordant data. Acute or chronic renal failure, thrombotic } \\
\text { microangiopathy, glomerulonephritis, tubular toxicity have been } \\
\text { reported }\end{array}$ & Variable \\
\hline $\begin{array}{l}\text { Metabolic } \\
\text { toxicity }\end{array}$ & $\begin{array}{l}\text { Hyperlipidemia (increased HDL, LDL, cholesterol and } \\
\text { triglycerids levels). Hyperglicemia }\end{array}$ & $\begin{array}{l}\text { Hyperlipidemia: } 21-37 \% \text { for temsirolimus, } 8-44 \% \text { for } \\
\text { everolimus, } 28-41 \% \text { for deforolimus. Hyperglicemia: } 8-22 \%\end{array}$ \\
\hline Infections & No evidence of significant immune suppression & Variable \\
\hline Malignancies & No evidence of significant increase in secondary malignancies & Variable \\
\hline
\end{tabular}




\section{CONCLUSION}

The recent discovery of the molecular mechanisms at the basis of tumorigenesis has permitted a more specific approach in the battle against malignancies. The m-TOR pathway has been recognized as one of the principle regulator of cellular growth, proliferation and angiogenesis in different tissues, as well as in tumoral lesions. The recognition of rapamycin and its analogues properties has opened the possibility to exercise an inhibition on tumoral development and spreading, as well as, at the same time, the modulation of the immune system activity. For these protean features, the so called "m-TOR inhibitors" have a primary importance in preventing tumor recurrence or the development of new tumors in transplanted patients, whose immune system must also be suppressed to avoid graft rejection. In the particular case of HCC, m-TOR pathway is only one of the complex and multiphasic processes involved in tumor progression. Therefore, it is intuitive that a "future" therapeutic approach should target the inhibition of the most part of these processes. However, since the creation of an ideal drug capable by itself to fulfill this proposal seems distant, to combine more therapeutic weapons could be the best way to, at least, control or delay tumor progression, or prevent tumor development.

\section{ABBREVIATIONS}

$\begin{array}{ll}\text { HCC } & =\text { Hepatocellular carcinoma } \\ \text { PTLD } & =\text { Post-transplant lymphoproliferative disease } \\ \text { TGF-b } & =\text { Transforming Growth Factor beta } \\ \text { VEGF } & =\text { Vascular Endothelial Growth Factor } \\ \text { FKBP12 } & =\text { FK-binding protein } \\ \text { PI3K } & =\text { Phosphatidylinositol 3-kinase } \\ \text { ATP } & =\text { Adenosine triphosphate } \\ \text { IGF-1 } & =\text { Insulin-like growth factor 1 } \\ \text { IRS } & =\text { Insulin receptor substrate } \\ \text { PIP3 } & =\text { Phosphatidylinositol-3, 4, 5- triphosphate } \\ \text { PDK1 } & =\text { Phosphatidylinositol-dependent kinase-1 } \\ \text { GTP } & =\text { Guanidine-5'-triphosphate } \\ \text { AMPK } & =5 \text { 'AMP-activated protein kinase } \\ \text { m-TORC1/2 } & \text { m-TOR-Complex 1/2 } \\ 4 E-B P 1 & =\text { Eukaryotic initiation factor 4E binding } \\ \text { S6K1 } & =\text { Protein-1 } \\ \text { HIF-1 } & =\text { Hypoxia inducible factor } \\ \text { PTEN } & =\text { Phosphatase and tensin homologue deleted } \\ \text { BRS } & \text { on chromosome 10 } \\ \text { CNI } & \text { Insulin receptor substrate } \\ \text { MEK } & \text { Barcelona Clinic Liver Cancer } \\ & \text { Calcineurin Inhibitor } \\ \text { Sinase }\end{array}$

ERK $=$ Extracellular signal-regulated kinase

VEGFR-2/3 = Vascular Endothelial Growth Factor Receptor $2 / 3$

PDGFR-b = Platelet-Derived Growth Factor beta

\section{REFERENCES}

[1] Rampone B, Schiavone B, Martino A, Viviano C, Confuorto G. Current management strategy of hepatocellular carcinoma. World J Gastroenterol. 2009; 15: 3210-6.

[2] Llovet JM, Burroughs A, Bruix J. Hepatocellular carcinoma. Lancet 2003; 362:1907-17.

[3] Okuda K. Hepatocellular carcinoma. J Hepatol 2000; 32: 225-37.

[4] Wong LL. Current status of liver transplantation for hepatocellular cancer. Am J Surg 2002; 183: 309-16.

[5] Yao FY. Liver transplantation for hepatocellular carcinoma: beyond the Milan criteria. Am J Transplant 2008; 8: 1982-9.

[6] Befeler AS, Hayashi PH, Di Bisceglie AM. Liver transplantation for hepatocellular carcinoma. Gastroenterology 2005; 128: 17521764.

[7] Silva M, Moya A, Berenguer M, et al. Expanded criteria for liver transplantation in patients with cirrhosis and hepatocellular carcinoma. Liver Transpl 2008; 14(10): 1449-60.

[8] Schwartz M, Roayaie S, Llovet J. How should patients with hepatocellular carcinoma recurrence after liver transplantation be treated? J Hepatol 2005; 43: 584-9.

[9] Zimmerman MA, Ghobrial RM, Tong MJ, et al. Recurrence of hepatocellular carcinoma following liver transplantation: a review of preoperative and postoperative prognostic indicators. Arch Surg 2008; 143: 182-8.

[10] Stone MJ, Klintmalm GB, Polter D, et al. Neoadjuvant chemotherapy and liver transplantation for hepatocellular carcinoma: a pilot study in 20 patients. Gastroenterology 1993; 104: 196-202.

[11] Roayaie S, Frischer JS, Emre SH, et al. Long-term results with multimodal adjuvant therapy and liver transplantation for the treatment of hepatocellular carcinomas larger than 5 centimeters. Ann Surg 2002; 235: 533-9.

[12] Cherqui D. Role of adjuvant treatment in liver transplantation for advanced hepatocellular carcinoma. J Hepatobiliary Pancreat Surg 1998; 5: 35-40.

[13] Söderdahl G, Bäckman L, Isoniemi H, et al. A prospective, randomized, multi-centre trial of systemic adjuvant chemotherapy versus no additional treatment in liver transplantation for hepatocellular carcinoma. Transpl Int 2006; 19: 288-94.

[14] Penn I. Occurrence of cancers in immunosuppressed organ transplant recipients. Clin Transpl 1998; 147-58.

[15] Kasiske BL, Synder JJ, Gilbertson DT, Wang C. Cancer after kidney transplantation in the United States. Am J Transplant 2004; 4: 905-13.

[16] Vasudev B, Hariharan S. Cancer after renal transplantation. Curr Opin Nephrol Hypertens 2007; 16: 523-8.

[17] Buell JF, Gross TG, Woodle WS. Malignancy after transplantation. Transplantation 2005; 80: S254-64.

[18] Dantal J, Pohanka E. Malignancies in renal transplantation: An unmet medical need. Nephrol Dial Transplant 2007; 22(suppl 1): i4-10.

[19] Kauffman HM, Cherikh WS, McBride MA, Cheng Y, Hanto DW. Post-transplant de novo malignancies in renal transplant recipients: The past and present. Transplant Int 2006; 19: 607-20.

[20] Vajdic CM, MacDonald SP, McCredie MR, et al. Cancer incidence before and after kidney transplantation. JAMA 2006; 296: 2823-31.

[21] Villeneuve PJ, Schaubel SS, Fenton SS, Shepherd FA, Jiang Y, Mao Y. Cancer incidence among Canadian kidney transplant recipients. Am J Transplant 2007; 7: 941-8.

[22] Jain A, Di Martini A, Kashyap R,Youk A, Rohal S, Fung J. Longterm follow-up after liver transplantation for alcoholic liver disease under Tacrolimus. Transplantation 2000; 70: 1335-42.

[23] Geissler EK. The impact of mTOR inhibitors on the development of malignancy. Transplant Proc 2008; 40: S32-5.

[24] Hojo M, Morimoto T, Maluccio M, et al. Cyclosporine induces cancer progression by a cell-autonomous mechanism. Nature 1999; 397: 530-4. 
[25] Maluccio M, Sharma VK, Lagman M, et al. Tacrolimus enhances transforming growth factor- $\alpha$, expression and promotes tumor progression. Transplantation 2003; 76: 597-602.

[26] Guba M, von Breitenbuch P, Steinbauer M, et al. Rapamycin inhibits primary and metastatic tumor growth by antiangiogenesis: involvement of vascular endothelial growth factor. Nat Med 2002; 8: 128-35.

[27] Vivarelli M, Cucchetti A, Piscaglia F, et al. Analysis of risk factors for tumor recurrence after liver transplantation for hepatocellular carcinoma: key role of immunosuppression. Liver Transpl 2005; 11: 497-503.

[28] Vivarelli M, Bellusci R, Cucchetti A, et al. Low recurrence rate of hepatocellular carcinoma after liver transplantation: better patient selection or lower immunosuppression? Transplantation 2002; 74: 1746-51

[29] Shi YH, Zhou J, Fan J. Treatment for the recurrence of hepatocellular carcinoma following liver transplantation: what is the best strategy? Cancer Biol Ther 2009; 8: 22-4.

[30] Treiber G. mTOR inhibitors for hepatocellular cancer: a forwardmoving target. Expert Rev Anticancer Ther 2009; 9: 247-61.

[31] Vezina C, Kudelski A, Sehgal SN. Rapamycin (AY-22,989), a new antifungal antibiotic. I. Taxonomy of the producing streptomycete and isolation of the active principle. J Antibiot (Tokyo) 1975; 28: 721-6.

[32] Alamo JM, Barrera L, Casado MD, et al. Efficacy, tolerance, and safety of mammalian target of rapamycin inhibitors as rescue immunosuppressants in liver transplantation. Transplant Proc 2009; 41: 2181-3.

[33] MacKenzie AR, von Mehren M. Mechanisms of mammalian target of rapamycin inhibition in sarcoma: present and future. Expert Rev Anticancer Ther 2007; 7 : 1145-54.

[34] Vivanco I, Sawyers CL. The phosphatidylinositol 3-Kinase AKT pathway in human cancer. Nat Rev Cancer 2002; 2: 489-501.

[35] Huang S, Houghton PJ. Targeting mTOR signaling for cancer therapy. Curr Opin Pharmacol 2003; 3: 371-7.

[36] Thomas GV. mTOR and cancer: reason for dancing at the crossroads? Curr Opin Genet Dev 2006; 16: 78-84.

[37] Hay N, Sonenberg N. Upstream and downstream of mTOR. Genes Dev 2004; 18: 1926-45.

[38] Kwiatkowski DJ. Tuberous sclerosis: from tubers to mTOR. Ann Hum Genet 2003; 67: 87-96.

[39] Kwiatkowski DJ. Rhebbing up mTOR: new insights on TSC1 and TSC2, and the pathogenesis of tuberous sclerosis. Cancer Biol Ther 2003; 2: 471-6.

[40] Inoki K, Li Y, Xu T, Guan KL. Rheb GTPase is a direct target of TSC2 GAP activity and regulates mTOR signaling. Genes Dev 2003; 17: 1829-34.

[41] Geissler EK, Schlitt HJ, Thomas G. mTOR, cancer and transplantation. Am J Transplant 2008; 8: 2212-8.

[42] Brugarolas J, Kaelin WG, Jr. Dysregulation of HIF and VEGF is a unifying feature of the familial hamartoma syndromes. Cancer Cell 2004; 6: 7-10.

[43] Corradetti MN, Inoki K, Bardeesy N, DePinho RA, Guan KL. Regulation of the TSC pathway by LKB1: evidence of a molecular link between tuberous sclerosis complex and Peutz-Jeghers syndrome. Genes Dev 2004; 18: 1533-8.

[44] Schmelzle T, Hall MN. TOR, a central controller of cell growth. Cell 2000; 103: 253-62.

[45] Hara K, Maruki Y, Long X, Yoshino K, Oshiro N, Hidayat S, Tokunaga C, Avruch J, Yonezawa K. Raptor, a binding partner of target of rapamycin (TOR), mediates TOR action. Cell 2002; 110 : 177-89.

[46] Kim DH, Sarbassov DD, Ali SM, et al. mTOR interacts with raptor to form a nutrient-sensitive complex that signals to the cell growth machinery. Cell 2002; 110: 163-75.

[47] Sarbassov DD, Ali SM, Kim DH, et al. Rictor, a novel binding partner of mTOR, defines a rapamycin-insensitive and raptorindependent pathway that regulates the cytoskeleton. Curr Biol 2004; 14: 1296-302.

[48] Sarbassov DD, Ali SM, Sengupta S, et al. Prolonged Rapamycin Treatment Inhibits mTORC2 Assembly and Akt/PKB. Mol Cell 2006; 22: 159-68.

[49] Sarbassov DD, Guertin DA, Ali SM, Sabatini DM. Phosphorylation and regulation of $\mathrm{Akt} / \mathrm{PKB}$ by the rictor-mTOR complex. Science 2005; 307: 1098-101.
[50] Bjornsti MA, Houghton PJ. The TOR pathway: a target for cancer therapy. Nat Rev Cancer 2004; 4: 335-48.

[51] Gambacorti-Passerini CB, Gunby RH, Piazza R, Galietta A, Rostagno R, Scapozza L. Molecular mechanisms of resistance to imatinib in Philadelphia-chromosome-positive leukaemias. Lancet Oncol 2003; 4: 75-85.

[52] Lang SA, Gaumann A, Koehl GE, et al. Mammalian target of rapamycin is activated in human gastric cancer and serves as a target for therapy in an experimental model. Int J Cancer 2007; 120: $1803-10$.

[53] Blagosklonny MV, Darzynkiewicz Z. Four birds with one stone: RAPA as potential anticancer therapy. Cancer Biol Ther 2002; 1 : 359-61.

[54] Zhong H, Chiles K, Feldser D, et al. Modulation of hypoxiainducible factor 1alpha expression by the epidermal growth factor/phosphatidylinositol 3-kinase/PTEN/AKT/FRAP pathway in human prostate cancer cells: implications for tumor angiogenesis and therapeutics. Cancer Res 2000; 15: 1541-5.

[55] Hay N. The Akt-mTOR tango and its relevance to cancer. Cancer Cell 2005; 8: 179-83.

[56] Lee DF, Kuo HP, Chen CT, et al. IKK beta suppression of TSC1 links inflammation and tumor angiogenesis via the mTOR pathway. Cell 2007; 130: 440-55.

[57] Samuels Y, Ericson K. Oncogenic PI3K and its role in cancer. Curr Opin Oncol 2006; 18: 77-82.

[58] Shah OJ, Hunter T. Tuberous sclerosis and insulin resistance. Unlikely bedfellows reveal a TORrid affair. Cell Cycle 2005; 4: 46-51.

[59] Sahin F, Kannangai R, Adegbola O, Wang J, Su G, Torbenson M. mTOR and P70 S6 kinase expression in primary liver neoplasms. Clin Cancer Res 2004; 10: 8421-5.

[60] Sieghart W, Fuereder T, Schmid K, et al. Mammalian target of rapamycin pathway activity in hepatocellular carcinomas of patients undergoing liver transplantation. Transplantation 2007; 83: 425-32.

[61] Baba HA, Wohlschlaeger J, Cicinnati VR, et al. Phosphorylation of p70S6 kinase predicts overall survival in patients with clear margin-resected hepatocellular carcinoma. Liver Int 2009; 29: 399405.

[62] Villanueva A, Chiang DY, Newell P, et al. Pivotal role of mTOR signaling in hepatocellular carcinoma. Gastroenterology 2008; 135 : 1972-83.

[63] Semela D, Piguet AC, Kolev M, et al. Vascular remodeling and antitumoral effects ofmTORinhibition in a rat model of hepatocellular carcinoma. J Hepatol 2007; 46: 840-8.

[64] Wullschleger S, Loewith R, Hall MN. TOR signaling in growth and metabolism. Cell 2006; 124: 471-84.

[65] Guertin DA, Sabatini DM. Defining the role of mTOR in cancer. Cancer Cell 2007; 12: 9-22.

[66] Sarbassov DD, Ali SM, Sabatini DM. Growing roles for the mTOR pathway. Curr Opin Cell Biol 2005; 17: 596-603.

[67] Brazelton TR, Morris RE. Molecular mechanisms of action of new xenobiotic immunosuppressive drugs: tacrolimus (FK506), sirolimus (rapamycin), mycophenolate mofetil and leflunomide. Curr Opin Immunol 1996; 8: 710-20.

[68] Sehgal SN. Sirolimus: its discovery, biological properties, and mechanism of action. Transplant Proc 2003; 35: 7S-14S.

[69] Sho M, Samsonov DV, Briscoe DM. Immunologic targets for currently available immunosuppressive agents: what is the optimal approach for children? Semin Nephrol 2001; 21: 508-20.

[70] Zeiser R, Leveson-Gower DB, Zambricki EA, et al. Differential impact of mammalian target of rapamycin inhibition on CD4_CD25_Foxp3_regulatory $T$ cells compared with conventional CD4_T cells. Blood 2008; 111: 453-62.

[71] Seufferlein T, Rozengurt E. Rapamycin inhibits constitutive p7R56K phosphorylation, cell proliferation, and colony formation in small cell lung cancer cells. Cancer Res 1996; 56: 3895-7.

[72] Schumacher G, Oidtmann M, Rosewicz S, et al. Sirolimus inhibits growth of human hepatoma cells in contrast to tacrolimus which provokes cell growth. Transplant Proc 2002; 34: 1392-3.

[73] Andrassy J, Graeb C, Rentsch M, Jauch KW, Guba M. mTOR inhibition and its effect on cancer in transplantation. Transplantation 2005; 80: 5171-4.

[74] Luan FL, Hojo M, Maluccio M, Yamaji K, Suthanthiran M. Rapamycin blocks tumor progression: Unlinking immunosup- 
pression from anti-tumor efficacy. Transplantation 2002; 73: 156572.

[75] Koehl GE, Andrassy J, Guba M, et al. Rapamycin protects allografts from rejection while simultaneously attacking tumors in immunosuppressed mice. Transplantation 2004; 77: 1319-26.

[76] Guba M, Koehl GE, Neppl E, et al. Dosing of rapamycin is critical to achieve an optimal antiangiogenic effect against cancer. Transpl Int 2005; 18: 89-94.

[77] Hudes G, Carducci M, Tomczak P, et al. Global ARCC Trial. Temsirolimus, interferon alfa, or both for advanced renal-cell carcinoma. N Engl J Med 2007; 356: 2271-81.

[78] Stallone G, Schena A, Infante B, et al. Sirolimus for Kaposi's sarcoma in renal-transplant recipients. N Engl J Med 2005; 352: 1317-23.

[79] Campistol JM, Gutierrez-Dalmau A, Torregrosa JV. Conversion to sirolimus: a successful treatment for posttransplantation Kaposi's sarcoma. Transplantation 2004; 77: 760-2.

[80] Babel N, Eibl N, Ulrich C, et al. Development of Kaposi's sarcoma under sirolimus-based immunosuppression and successful treatment with imiquimod. Transplant Infect Dis 2007; 10: 59-62.

[81] Buell J, Beebe TM, Hanaway MJ, et al. Malignancies associated with liver transplantation. In: Busuttil RW, Klintmalm AB, Eds. Transplantation of the liver. Philadelphia, WB Saunders 2004; pp. 1149.

[82] Kneteman NM, Oberholzer J, Al Saghier M, et al. Sirolimus-based immunosuppression for liver transplantation in the presence of extended criteria for hepatocellular carcinoma. Liver Transpl 2004; 10: 1301-11.

[83] Wall WJ. Hepatocellular cancer, transplantation, and sirolimus. Liver Transpl 2004; 10: 1312-4.

[84] Toso C, Merani S, Bigam DL, Shapiro AM, Kneteman NM. Sirolimus-based immunosuppression is associated with increased survival after liver transplantation for hepatocellular carcinoma. Hepatology 2010; 51: 1237-43.

[85] Wang CX, Liu LS, Chen LZ, et al. Characteristics of neoplasm occurrence and the therapeutic effect of sirolimus in South Chinese kidneytransplant recipients. Transplant Proc 2006; 38: 3536-9.

[86] Elsharkawi M, Starb L, Henne-Briers D, Mayer J. Complete remission of post-transplant lung metastases from hepatocellular carcinoma undertherapy with sirolimus and mycophenolate mofetil. Transplantation 2005; 77: 855-7.

[87] Stippel DL, Kasper HU, Schleimer K, et al. Successful use of sirolimus in a patient with bulky ovarian metastases of hepatocellular carcinoma after liver transplantation. Transplant Proc 2005; 37: 2185-7.

[88] Zimmerman MA, Trotter JF, Wachs M, et al. Predictors of longterm outcome following liver transplantation for hepatocellular carcinoma:A single center experience. Transpl Int 2007; 20: 74753.

[89] Zhang JF, Liu JJ, Lu MQ, et al. Rapamycin inhibits cell growth by induction of apoptosis on hepatocellular carcinoma cells in vitro. Transpl Immunol 2007; 17: 162-8.

[90] Koehl G, Gaumann A, Zuelke C, et al. Development of de novo cancer in p53 knock-out mice is dependent on the type of long-term immunosuppression used. Transplantation 2006; 82: 741-8.

[91] Morales JM, Campistol JM, Kreis H, et al. Sirolimus-based therapy with or without cyclosporine: long-term follow-up in renal transplant patients. Transplant Proc 2005; 37: 693-6.

[92] Mathew T, Kreis H, Friend P. Two year incidence of malignancy in Sirolimus-treated renal transplant recipients: Results from five multicenter studies. Clin Transplant 2004; 18: 446-9.

[93] Kahan BD, Yakupoglu YK, Schoenberg L, et al. Low incidence of malignancy among sirolimus/cyclosporine treated renal transplant recipients. Transplantation 2005; 80: 749-58.

[94] Yakupoglie YK, Buell JF, Woodle S, Kahan BD. Individualization of immunosuppressive therapy. III. Sirolimus associated with a reduced incidence of malignancy. Transplant Proc 2005; 38: 35861.

[95] Pirsch JD. Cytomegalovirus infection and post-transplant lymphoproliferative disease in renal transplant recipients: Results of the U.S. multicenter FK506 kidney transplant study group. Transplantation 1999; 68: 1203-5.

[96] Cherikh WS, Kauffman M, Delmonico F. A multicenter analysis of discharge immunosuppression and post-transplant malignancy. Am J Transplant 2001; 1: 353 .
[97] Kauffman HM, Cherikh WS, Cheng Y, Hanto DW, Kahan BD. Maintenance immunosuppression with target of rapamycin inhibitors is associated with reduced incidence of de novo malignancies. Transplantation 2005; 80: 883-9.

[98] Zmonarski SC, Boratynska M, Rabczynski J, Kazimierczak K, Klinger M. Regression of Kaposi's sarcoma in renal graft recipients after conversion to sirolimus treatment. Transplant Proc 2005; 37: 964-6.

[99] Stallone G, Infante B, Pontrelli $\mathrm{P}$, et al. ID2-VEGF-related pathways in the pathogenesis of Kaposi's sarcoma: a link disrupted by rapamycin. Am J Transplant 2009; 9: 558-66.

[100] Gheith O, Bakr A, Wafa E, et al. Sirolimus for visceral and cutaneous Kaposi's sarcoma in a renal transplant recipient. Clin Exp Nephrol 2007; 11: 251-4.

[101] Kolhe N, Mamode N, Van der Walt J, Pattison J. Regression of posttransplant Kaposi's sarcoma using sirolimus. Int J Clin Pract 2006; 60: 1509-12.

[102] Lebbe C, Euvrard S, Barrou B, et al. Sirolimus conversion for patients with post transplant Kaposi's sarcoma. Am J Transplant 2006; 6: 2164-8.

[103] Descoeudres B, Graf T, Steiger J, Mayr M. No effect of Sirolimus for Kaposi's sarcoma in a renal transplant recipient. Transplantation 2006; 81: 1472-4.

[104] Wasywich CA, Croxson MC, van Doornum GJ, Coverdale HA, Ruygrok PN. Sirolimus for Kaposi's sarcoma. J Heart Lung Transplant 25; 6: 726-9.

[105] Boratynska M, Zmonarski SC, Klinger M. Recurrence of Kaposi's sarcoma after increased exposure to sirolimus. Int Immunopharmacol 2006; 6: 2018-22.

[106] Segolini GP, Giraudi R, Messina M, et al. No recurrence of Kaposi's sarcoma in a case of renal retransplantation under calcineurin inhibitor free immunosuppressive regimen: First report. Transpl Int 2007; 20: 395-6.

[107] Campistol JM, Eris J, Oberbauer R, et al. Sirolimus therapy after early cyclosporine withdrawal reduces the risk for cancer in adult renal transplantation. J Am Soc Nephrol 2006; 17: 581-9.

[108] Tessmer CS, da Silva Magalhaes LV, et al. Conversion to sirolimus in renal transplant recipients with skin cancer [letter to the editor]. Transplantation 2006; 82: 1792-3.

[109] Fernandez A, Marcen R, Pascual J, et al. Conversion from calcineurin inhibitors to everlimus in kidney transplant recipients with malignant neoplasia. Transplant Proc 2006; 38: 2453-5.

[110] Pascual J. Everolimus in clinical practice-Renal transplantation. Nephrol Dial Transplant 2006; 21: iii18-23.

[111] de Fijter JW. Use of proliferation signal inhibitors in nonmelanoma skin cancer following renal transplantation. Nephrol Dial Transplant 2007; 22: i23-6.

[112] Levi Z, Hazazi R, Kedar-Barnes I, et al. Switching from tarolimus to sirolimus halts the appearance of new sebaceous neoplasms in Muir-Torre syndrome. Am J Transplant 2007; 7: 479.

[113] Morard I, Dumortier J, Spahr L, et al. Conversion to sirolimusbased immunosup-pression in maintenance liver transplant patients. Liver Transpl 2007; 13: 658-64.

[114] Zaltzman JS, Prasad R, Chun K, Jothy S. Resolution of renal allograftassociated post transplant lymphoproliferative disorder with introduction of sirolimus. Nephrol Dial Transplant 2005; 20: 1748-51.

[115] Mohsin N, Budrudden M, Kamble P, et al. Complete regression of cutaneous B cell lymphoma in a renal transplant patient after conversion from cyclosporine to sirolimus. Transplant Proc 2007; 39: $1267-71$.

[116] Cullis B, D’Souza R, McCullagh P, et al. Sirolimus-Induced remission of posttransplantation lymphoproliferative disorder. Am J Kidney Dis 2006; 47: E67-72.

[117] Jimenez-Rivera C, Avitur Y, Fecteau A, Jones N, Grant D, Ng VL. Sirolimus for pediatric liver transplant recipients with posttransplant lymphoproliferative disease and hepatoblastoma. Pediatr Transplant 2004; 8: 243-8.

[118] Garcia VD, Bonamigo FJL, Neuman J, et al. Rituximab in association with rapamycin for posttransplant lymphoproliferative disease treatment. Transpl Int 2003; 16: 202-6.

[119] Al Akash S, Al Makadama A, Al Omari MG. Rapid reponse to rituximab in a pediatric liver transplant recipient with posttransplant lymphoproliferative disease and maintenance with sirolimus monotherapy. Pediatr Transplant 2005; 9: 249-53. 
[120] Snavely WR, Sonabend M, Rosen T. Posttransplant Epstein-Barr virus related lymphoproliferative disorder with a primary cutaneous presentation. Dermatol Online J 2007; 13: 7.

[121] Bruce AJ, Subtil A, Rogers RS III, Castro LA. Monomorphic Epstein-Barr virus (EBV)-associated large B cell posttransplant lymphoproliferative disorder presenting as a tongue ulcer in a pancreatic transplant patient. Oral Surg Oral Med Oral Pathol Oral Radiol Endod 2006; 102: e24-8.

[122] Sánchez-Fructuoso A, Conesa J, Perez Flores I, et al. Conversion to sirolimus in renal transplant patients with tumors. Transplant Proc 2006; 38: 2451-2.

[123] Gomez-Camarero J, Salcedo M, Rincon D, et al. Use of everolimus as a rescue immunosuppressive therapy in liver transplant patients with neoplasms. Transplantation 2007; 84: 786-91.

[124] Boratynska M, Watozek E, Smolska D, Patrzałek D, Klinger M. Anticancer effect of sirolimus in renal allograft recipients. Transplant Proc 2007; 39: 2736-9.

[125] Bonatti H, Hoefer D, Rogatsch H, Margreiter R, Larcher C, Antretter H. Successful management of recurrent Epstein-Barr virus associated leiomyosarcoma after cardiac transplantation. Transplant Proc 2005; 37: 1839-44.

[126] Toh HC, Teo M, Ong KW, et al. Use of sirolimus for Epstein-Barr virus-positive smooth-muscle tumor. Lancet Oncol 2006; 7: 955-7.

[127] Huynh H, Nguyen TT, Chow KH, Tan PH, Soo KC, Tran E. Overexpression of the mitogen-activated protein kinase (MAPK) kinase (MEK)-MAPK in hepatocellular carcinoma: its role in tumor progression and apoptosis. BMC Gastroenterol 2003; 3: 19.

[128] Huynh H, Ngo VC, Koong HN, et al. AZD6244 enhances the antitumor activity of sorafenib in ectopic and orthotopic models of human hepatocellular carcinoma (HCC). J Hepatol 2010; 52: 7987.
[129] Yea S, Narla G, Zhao X, et al. Ras promotes growth by alternative splicing-mediated inactivation of the KLF6 tumor suppressor in hepatocellular carcinoma. Gastroenterology 2008; 134: 1521-31.

[130] Challen C, Guo K, Collier JD, Cavanagh D, Bassendine MF. Infrequent point mutations in codons 12 and 61 of ras oncogenes in human hepatocellular carcinomas. J Hepatol 1992; 14: 342-6.

[131] Lerman MI, Minna JD. The 630-kb lung cancer homozygous deletion region on human chromosome $3 \mathrm{p} 21.3$ : identification and evaluation of the resident candidate tumor suppressor genes. The International Lung Cancer Chromosome 3p21.3 Tumor Suppressor Gene Consortium. Cancer Res 2000; 60: 6116-33.

[132] Hesson L, Dallol A, Minna JD, Maher ER, Latif F. NORE1A, a homologue of RASSF1A tumor suppressor gene is inactivated in human cancers. Oncogene 2003; 22: 947-54.

[133] Newell P, Toffanin S, Villanueva A, et al. Ras pathway activation in hepatocellular carcinoma and anti-tumoral effect of combined sorafenib and rapamycin in vivo. J Hepatol 2009; 51: 725-33.

[134] Kim A, Balis FM, Widemann BC. Sorafenib and sunitinib. Oncologist 2009; 14(8): 800-5.

[135] Huynh H, Ngo VC, Koong HN, et al. Sorafenib and rapamycin induce growth suppression in mouse models of hepatocellular carcinoma. J Cell Mol Med 2009; 13: 2673-83.

[136] Wang Z, Zhou J, Fan J, et al. Effect of rapamycin alone and in combination with sorafenib in an orthotopic model of human hepatocellular carcinoma. Clin Cancer Res 2008; 14: 5124-30.

[137] Geissler EK. Fighting malignancy in organ transplant recipients. Transplant Proc 2009; 41: S9-12.

[138] Sankhala K, Mita A, Kelly K, Mahalingam D, Giles F, Mita M. The emerging safety profile of mTOR inhibitors, a novel class of anticancer agents. Target Oncol 2009; 4: 135-42.

\section{(C) Ponziani et al.; Licensee Bentham Open.}

This is an open access article licensed under the terms of the Creative Commons Attribution Non-Commercial License (http://creativecommons.org/ licenses/by-nc/3.0/), which permits unrestricted, non-commercial use, distribution and reproduction in any medium, provided the work is properly cited. 